\title{
Natural Enemy Complex of Some Agroforestry Systems of Aizawl and Their Implications in Insect Pest Management
}

\author{
Rosy Lalnunsangi ${ }^{1}$, Dibyendu Paul ${ }^{2} \&$ Lalit Kumar $\mathrm{Jha}^{2}$ \\ ${ }^{1}$ Department of Zoology, Mizoram University, Aizawl, Mizoram, India \\ ${ }^{2}$ Department of Environmental Studies, North Eastern Hill University, Shillong, Meghalaya, India \\ Correspondence: Rosy Lalnunsangi, Department of Zoology, Mizoram University, Aizawl, Mizoram, India. Tel: \\ 91-943-615-3083. E-mail: rose_khiangte@yahoo.com
}

\author{
Received: October 28, 2013 Accepted: March 20, 2014 Online Published: April 30, 2014 \\ doi:10.5539/eer.v4n2p29 \\ URL: http://dx.doi.org/10.5539/eer.v4n2p29
}

\begin{abstract}
Agroforestry systems of the hilly regions of the north east are small scale, primitive land use systems, evolving through traditional knowledge requiring very little inputs in terms of irrigation, fertilizers and pesticides. The different components of the agroforestry systems were analyzed for their natural enemy complex through a monthly sampling programme. Maintenance and potential role of natural enemies' complex in various compartments of such systems are discussed in the light of land use practices and holding size.
\end{abstract}

Keywords: small scale, agroforestry, insect pest, natural enemy complex

\section{Introduction}

In Mizoram the practice of shifting cultivation also termed as "jhum" or "slash and burn" is still the predominant form of agriculture. This form of agriculture is subsistence level agriculture and is generally rainfed, often resulting in an enormous erosive soil loss during the heavy monsoons.

Among the various alternative to jhum, agroforestry is increasingly becoming popular because of its ameliorative potential and conservation of the biophysical characteristics of soil. Many of the benefits of agroforestry are derived from the increased diversity of these systems compared to traditional agricultural management practices (Holloway \& Stork, 1991). In Mizoram traditional forms of agroforestry have been practiced by some farmers in their own way. It was first innovated by Jha and Lalnunmawia (2000, 2003) and named them as Tree-Greenhedge-Crop farming system and Bamboo based agroforestry system respectively. The various multipurpose tree species and predominant agroforestry systems prevalent in Mizoram have been reported by Lalramnghinglova and Jha (1996). Teak (Tectona grandis) is an indigenous timber species of the state occurring both naturally and in plantations. Traditional systems having Tectona grandis (Verbenaceae) and crops like Zea mays (Poaceae) and Oryza sativa (Poaceae) are the most common and successful agroforestry practices, particularly during the seedling, sapling/pole stages of growth of the tree component. Subsequently, depending on the existing spacing, cropping is abandoned if the canopy of the tree component closes; otherwise it is continued, simulating true agroforestry systems. Cultivation of paddy, maize or vegetables along with tung (Aleurites sp.) is another common combination in the state.

The insect fauna occurring on certain plant species, in any particular location, is more or less the same, whether that plant species is in monoculture or in a polycultural assemblage such as an agroforestry system. However, the activities of these insects are not likely to be identical in any two situations. There are several factors that influence the activities of insects in agroforestry and among these the role played by natural enemies is substantial.

The present investigation focuses on comparing the distribution of natural enemy complex in teak, tung and subabul based agroforestry system of Aizawl.

\section{Materials and Methods}

\subsection{Study Site}

The study was conducted in the outskirts and within Aizawl, which is the capital of Mizoram. It lies between $20^{\circ} 58^{\prime}-24^{\circ} 35^{\prime} \mathrm{N}$ latitudes and $92^{\circ} 15^{\prime}-93^{\circ} 29^{\prime} \mathrm{E}$ longitudes with an average annual rainfall of $2500 \mathrm{~mm}$. Three 
experimental plots were selected, one each at Chanmari west, Zemabawk, and Sakawrtuichhun. For the purpose of sampling, each experimental plot was subdivided into three components, viz, tree, crop and fringe area component, each having an area of approximately $100 \mathrm{~m} \times 100 \mathrm{~m}$.

The tree components of these sites were repectively Teak (Tectona grandis), Tung (Aleurites fordii) and Subabul (Leucaena leucocephala). The crop component in all the sites were maize (Zea mays), Phaseolus vulgaris and/ or Vigna sinensis. Besides, the teak site also had Clerodendrum colebrookianum and Solanum indicum as other components. The fringe area comprises the natural vegetation immediately outside the cropping area and comprises weed species such as Imperata cylindrica L., Drymaria chordate L. (Caryophyllaceae), Cyperus rotundus L. (Cyperaceae), Eupatorium sp, Ageratum conyzoides L. (Asteraceae), etc. were common in the sites.

\subsection{Sampling}

A random sampling program (Southwood, 1978), replicated five times was undertaken for two years in each component of each site. The samplings were done by using sweep net or through handpicking. The fringe area and crop plots were sampled through sweeping with an insect collecting net. The sweep was adjusted such that each sweep covered an area of $1 \mathrm{~m}^{2}$. Sampling through hand picking was undertaken for individual crop plants and tree components. All samples were replicated five times. The insects collected were identified from FRI Dehra Dun, ZSI, Shillong and ICAR, Shillong.

\section{Results and Discussion}

The natural enemy complex in order of importance encountered during the course of the study belongs to the following orders:

Mantoidea, Chilopoda, Hymenoptera, Araneida, Dermaptera, Hemiptera, Coleoptera.

Praying mantids were observed to frequent the cropping plots for preying. The undisturbed fringe area vegetation and the tree components provided refugia. The ability to fly also afforded a longer range of operation. The undisturbed (untilled) soils and litter around the tree component provided habitat conditions for the centipides (Chilopoda). Their ability to enter nooks and crevices made them excellent predators seeking out larvae. Ground foraging ants were ubiquitous in the cropping area. Wasps were also attracted to the cropping plots and the tree component and fringe area housed their nests. Hemiptera were observed to stay camouflaged on the bark of the tree component. Dermaptera and coleoptera were mostly encountered on the crop components foraging for larvae and aphids. Araneida (hunting spiders) were observed to actively seek prey on crop plants. Besides webs were also seen to trap small flying insects such as aphids, dipteral and coleopteran.

The percentage composition of the different arthropod orders in the Aleurites site of Aizawl is depicted in Figure 1. The tree component had 6 representative groups with araneida (15\%), chilopoda (10\%) and hymenoptera $(21 \%)$, the three predatory groups constituting $46 \%$ of the total fauna while the predatory groups of the crop component were represented by dermaptera $(11 \%)$, homoptera $(14 \%)$, and hymenoptera (33\%), i.e a total predatory fauna of $58 \%$. The fringe area had 10 representative groups including larvae and the predatory fauna constituted $33 \%$ of the total fauna through araneida (11\%), mantoidea (6\%), hymenoptera (10\%) and dermaptera $(6 \%)$.

The percentage composition of the different arthropod orders in the Teak site of Aizawl is depicted in Figure 2. The tree component had 8 representative groups with araneida (10\%), mantoidea $(23 \%)$ and hymenoptera (18\%) the three exclusively predatory groups constituting $51 \%$ of the total fauna. Among the crop component too, the predatory group constitute $33 \%$ of the total fauna through araneida (7\%), chilopoda (5\%) and hymenoptera $(21 \%)$. The fringe area component had 8 representative groups, and predators constituted $47 \%$ of the total fauna, and consisting of mantoidea (13\%), hymenoptera (22\%) and araneida $(12 \%)$.

The percentage composition of the different arthropod orders in the Leucaena site of Aizawl is depicted in Figure 3. The number of representative groups was 6,5 and 10 in the tree, crop and fringe area components respectively and the predatory fauna constituted $26 \%$ through the orders dermaptera (11\%), chilopoda (6\%) and araneida $(10 \%)$ in the tree area component and the predatory in the crop component is represented by $48 \%$ hymenoptera while $46 \%$ of the total predatory fauna in the fringe area components are constituted by hymenoptera $(17 \%)$, araneida (9\%), mantoidea (17\%), dermaptera $(7 \%)$. 


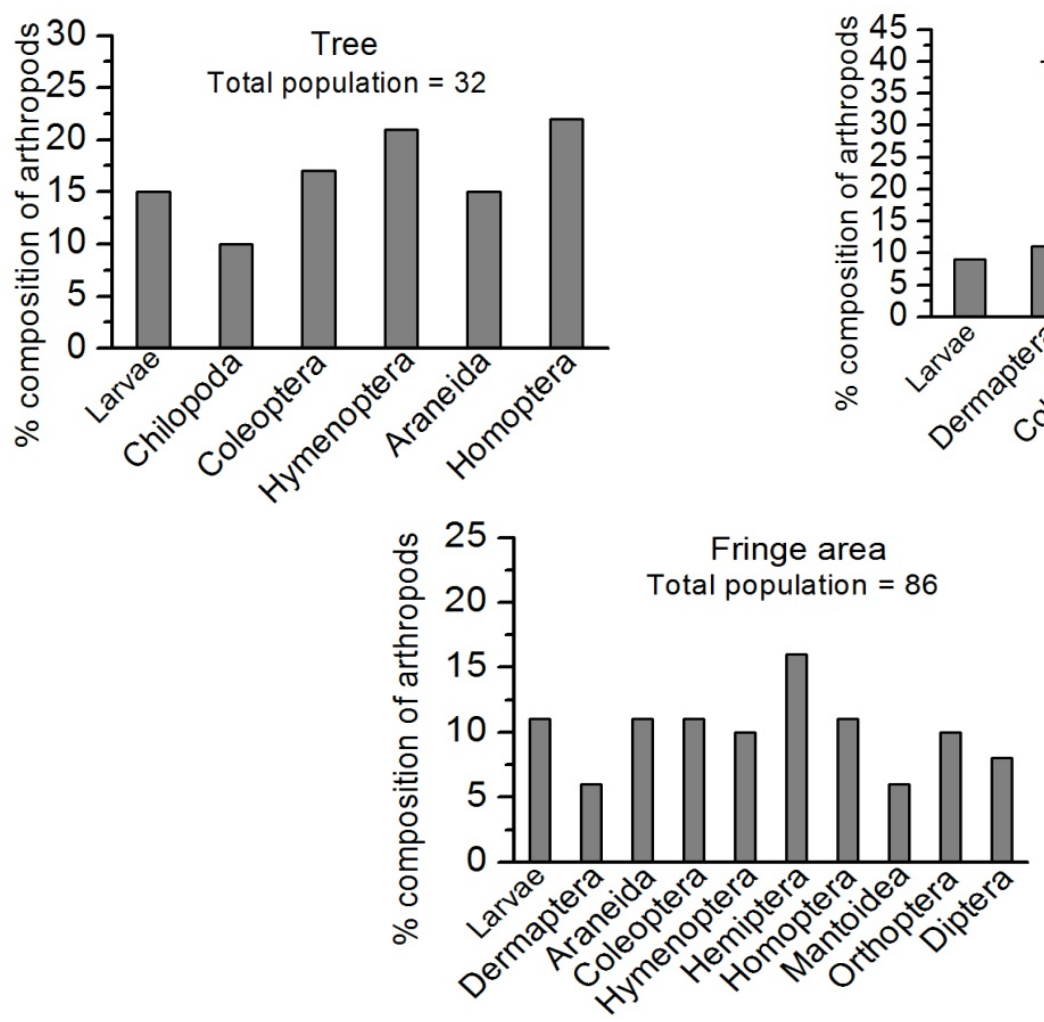

Figure 1. Percentage composition of arthropods in different plant habits (tree, crop and fringe) of Tung (Aizawl) site
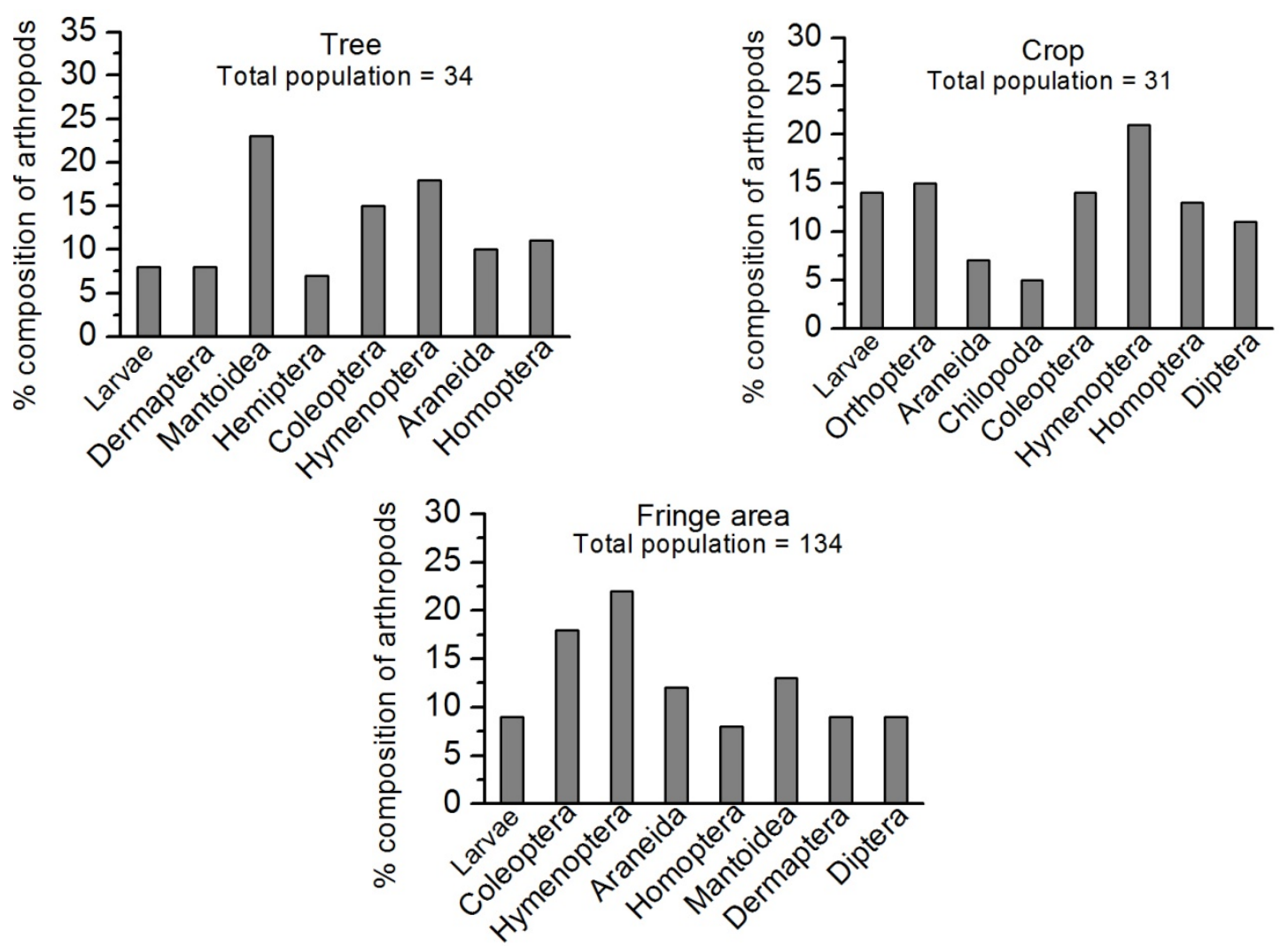

Figure 2. Percentage composition of arthropods in different plant habits (tree, crop and fringe) of Teak (Aizawl) site 

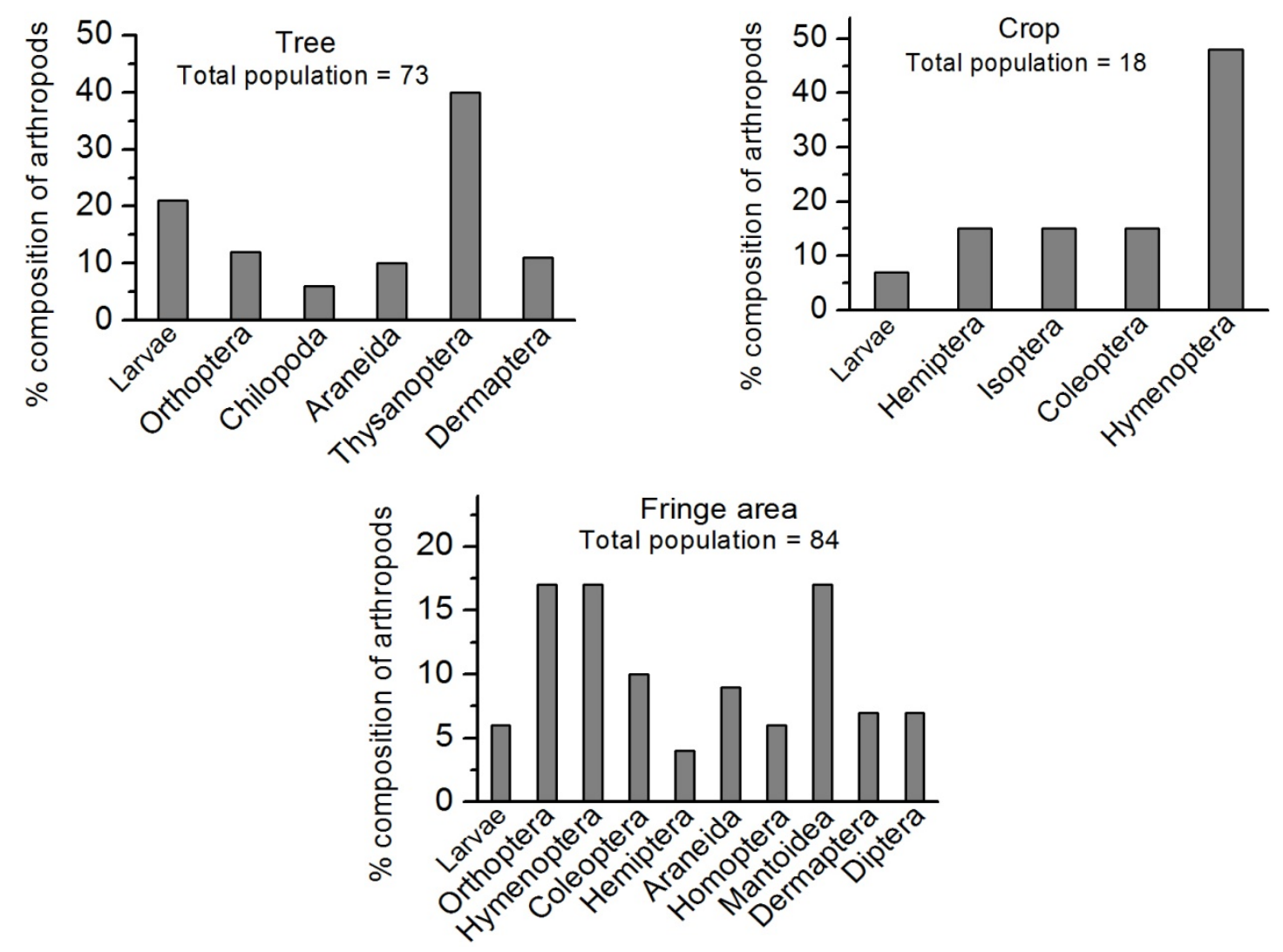

Figure 3. Percentage composition of arthropods in different plant habits (tree, crop and fringe) of Subabul (Aizawl) site

Agroforestry systems, particularly the complex ones, have a great potential for controlling pest populations through increasing the efficiency of biological control agents. Biological control by parasites/predators has been proved to be an excellent alternative to chemical pesticides in many ecosystems (Sithananthan et al., 1973; De Bach, 1974; Hagen et al., 1976; Kring et al., 1985; Yadav et al., 1985; Manjunath, 1988; Singh \& Jalali, 1992).

The low level of infestation in the tree component is indicative of natural control through predator complex operating both from within and from the fringe area. The fringe area composing of dense, diverse vegetation, harbor different natural enemy population. Higher densities of predator species in dense vegetation have been reported by Sprenkel et al. (1979) and Horn (1981).

Diversified cropping systems based on agroforestry, cover cropping are considered more stable and more resource conserving (Vandermeer, 1995). Alteieri and Letourneau (1984) reported the effects of plant diversity on the regulation of insect herbivore populations by favouring the abundance and efficacy of associated natural enemies. Agroforestry, being perennial, along with the fringe area support the natural enemy complex within and between seasons, especially during the off season of the main crop by offering alternate prey, pollen and nectar sources and suitable micro-habits for parasitoids and predators (Jervis \& Kidd, 1996; Landis et al., 2000; Begum et al., 2006)

The natural enemy complex operative in the systems is diverse and constitute a sizeable percentage of the total fauna. The presence of Hymenopterans like wasps and parasitoids are indicative of their potential in infesting the pest larval stages. Wasps have been observed to actively predate upon pest larvae. These larvae are enclosed in egg cases as food for the growing wasp larvae. Mantids and Chilopoda have been observed to predate upon a wide variety of insects such as larvae, orthopterans and cicada. Further, hymenoptera (Formicidae) have also been observed to forage and predate upon insect larvae. Dermaptera and coleopterans were seen to predate upon aphids. The presence of the fringe area of natural undisturbed vegetation is probably crucial in maintenance of such a healthy predatory complex. Further, the small size of the crop holdings $\left(\approx 100 \mathrm{~m}^{2}\right)$ ensures easy access of the whole plot to the natural enemy complex. The presence of untilled area around the tree component also provides undisturbed habitable conditions for predatory ground fauna like Chilopoda and predatory Coleoptera. 
All these conditions contribute to a strong predatory component and is reflective of the low pest infestations.

\section{References}

Altieri, M. A., \& Letourneau, D. K. (1984). Vegetation diversity and insect pests outbreaks. CRC Critical Reviews in Plant Sciences, 2, 131-169. http://dx.doi.org/10.1080/07352688409382193

Begum, M., Gurr, G. M., Wrattan, P. R., \& Nicol, H. I. (2006). Using selective food plants to maximize biological control of vineyards pests. Journal of Applied Ecology, 43, 547-554. http://dx.doi.org/10.1111/j.1365-2664.2006.01168.x

De Bach, P. (1974). Biological control by natural enemies (p. 322). London: Cambridge Uinv., Press.

Hagen, K. S., Bombosch, S., \& Mc Murtry, J. A. (1976). The biology and impact of predators. In C. B. Huffaker $\&$ P. S. Messenger (Eds.), Theory and practice of biological control. San Diego: Academic.

Holloway, J. D., \& Stork, N. E. (1991). The dimensions of biodiversity: the use of invertebrates as indicators of human impact. In D. L. Hawksworth (Ed.), The Biodiversity of Microorganisms and Invertebrates; Its Role in Sustainable Agriculture (pp. 37-62). CAB International, Wallingford, UK.

Horn, D. J. (1981). Effect of weedy backgrounds on colonization of collards by green peach aphid, Myzus persicae, and its major predators. Environmental Entomology, 10(3), 285-289.

Jervis, M. A., \& Kidd, N. A. C. (1996). Phytophagy. In M. A. Jervis, \& N. A. C. Kidd (Eds.), Insect Natural Enemies (pp. 375-394). London: Chapman and Hall.

Jha, L. K., \& Lalnunmawia, F. (2003). Agroforestry with bamboo and ginger to rehabilitate degraded areas in North East India. J. Bamboo and Rattan, 2, 103-109. http://dx.doi.org/10.1163/156915903322320739

Kring, T. J., Gilstrap, F. E., \& Michels, Jr. G. J. (1985). Role of indigenous coccinellids in regulating greenbugs (Homoptera: Aphididae) on Texas grain sorghum. J. Econ. Entomol, 78, 269-273.

Lalramnghinglova, J. H., \& Jha, L. K. (1996). Prominent agroforestry systems and important multipurpose trees in farming system of Mizoram. The Indian Forester, 122, 604-609.

Landis, D. A., Wratten, S. D., \& Gurr, G. M. (2000). Habitat management to conserve natural enemies of arthropod pests in agriculture. Annual Review of Entomology, 45, 175-201. http://dx.doi.org/10.1146/annurev.ento.45.1.175

Manjunath, T. M. (1988). Mass production and utilization of Trichogramma. In Biocontrol Technology for sugarcane pests: Proceedings of National Symposium (pp. 249-253). Sugarcane Breeding Institute, ICAR, Combaitore.

Singh, S. P., \& Jalali, S. K. (1992). Biological suppression of Chilo auricilius on sugarcane in India. Trichogramma News, 6, 25.

Sithanantham, S., Muthusamy, S., \& Durai, R. (1973). Experiments on the inundative release of Trichogramma australicum (Gir.) in the biological control of sugarcane stem borer, Chilo indicus Kapur. Madras Agricultural Journal, 60, 457-461.

Sprenkel, R. K., Brooks, W. M., van Duyn J. W., \& Deitz, L. L. (1979). The effect of three cultural variables on the incidence of Nomuraea rileye, phytophagous Lepidoptera, and their predators on soybeans. Environmental Entomology, 8, 334-339.

Vandermeer, J. (1995). The ecological basis of alternative agriculture. Annual Review of Ecology Systems, 26, 201-224. http://dx.doi.org/10.1146/annurev.es.26.110195.001221

Yadav, D. N., Patel, R. C., \& Patel, D. S. (1985). Impact of inundative release of Trichogramma chilonis Ishii against Heliothis armigera (Hubn.) in Gujarat. Journal of Entomological Research, 9(2), 153-159.

\section{Copyrights}

Copyright for this article is retained by the author(s), with first publication rights granted to the journal.

This is an open-access article distributed under the terms and conditions of the Creative Commons Attribution license (http://creativecommons.org/licenses/by/3.0/). 